\title{
Effect of sublethal doses of abamectin on demographic traits of tomato leafminer Tuta absoluta (Meyrick, 1917) (Lepidoptera: Gelechiidae)
}

\author{
Idin Zibaee*, Mojtaba Esmaeily \\ Department of Plant Protection, Agricultural and Natural Resources Campus, University of Tehran, Karaj, Iran
}

Vol. 57, No. 3: 256-267, 2017

DOI: 10.1515/jppr-2017-0036

Received: February 02, 2017

Accepted: August 24, 2017

${ }^{*}$ Corresponding address: aidin_zibaei@yahoo.com

\begin{abstract}
The tomato leafminer, Tuta absoluta is a serious pest of tomato crops worldwide. In this study the effect of sublethal concentrations of abamectin (at 10 and 30\% lethal concentrations, $\mathrm{LC}_{10}$ and $\mathrm{LC}_{30}$ ) was investigated on developmental and reproduction parameters of the tomato leafminer Tuta absoluta. Lethal concentrations were estimated by leaf dip bioassay on the fourth instar larvae of the T. absoluta that, $\mathrm{LC}_{50}, \mathrm{LC}_{30}$ and $\mathrm{LC}_{10}$ were $0.23,0.15$ and $0.12 \mathrm{mg} \cdot \mathrm{l}^{-1}$, respectively. The sublethal concentrations led to significant decreases in adult emergence, the percentage of pupation of the parent generation, fecundity and adult longevity compared to the control. Sublethal concentrations significantly decreased the net reproductive rate $\left(R_{0}\right)$, intrinsic rate of increase $(r)$, finite rate of increase $(\lambda)$, and gross reproduction rate $(G R R)$. There was a significant decrease in the time to egg developmental and doubling time $(D T)$ of T. absoluta. However, sublethal concentrations of abamectin had no significant effects on the percentage of pupation, larva, prepupa and pupa developmental periods, hatchability and sex ratio of offspring. The results of this study indicated that sublethal concentrations of abamectin could influence some biological parameters of T. absoluta. The results could also be helpful for making better management decisions for controlling the tomato leafminer.
\end{abstract}

Key words: abamectin, life table, sublethal effects, tomato leafminer, Tuta absoluta

\section{Introduction}

Sublethal doses of different insecticides could affect the physiological and behavioral properties of insects (Haynes 1988). These effects are defined as physiological or behavioral effects on insect individuals that survive exposure to pesticides (Desneux et al. 2007). The estimation of sublethal effects of insecticides could provide insight into insect pest control without any harmful effects on their natural enemies (Stapel et al. 2000; Stark and Banks 2003). Physiological effects may be manifested as shorter life spans and developmental time, as well as lower weights of larvae, pupae, and adults. Also reduced are adult longevity, hatchability, fecundity, egg size and reproduction parameters such as the net reproductive rate $\left(R_{0}\right)$, intrinsic rate of increase $(r)$, finite rate of increase $(\lambda)$, generation time
$(T)$, doubling time $(D T)$ and the sex ratio (Ripper 1956; Jones and Parrella 1984; Desneux et al. 2007; Yin et al. 2008; Cloyd 2012). Behavioral changes may affect feeding (Stapel et al. 2000), olfactory learning (E1 Hassani et al. 2005), searching (Dabrowski 1969) and ovipositioning (Fujiwara et al. 2002). Since individuals that survive insecticide exposure may still sustain significant damage, the multiple sublethal effects as well as mortality must be considered when examining the total effects of insecticides.

Avermectins are a group of fermentation products from the soil bacterium Streptomyces avermitilis. They are 16-membered macrocyclic lactones with potent nematicidal, acaricidal and insecticidal activities (Clark et al. 1995). Avermectins are extremely toxic to various 
orders of insects and mites. They also disrupt development (Robertson et al. 1985; Deecher et al. 1990) and reproduction (Bariola 1984; Robertson et al. 1985). Siqueira et al. (2001) showed the toxicity of abamectin in different populations of tomato leafminer. Reed et al. (1985) found significant delays in larval development in Cydia pomonella Linnaeus, 1758) (Lep.:Totricidae) when the eggs were treated with high rates of abamectin. Lepidopteran larvae treated with abamectin have generally been shown to have difficulties in mating (Beach and Todd 1985) or reduced fecundity and fertility (Reed et al. 1985; Robertson et al. 1985; Strong and Brown 1987). Sublethal doses of abamectin increased the developmental time from neonate to adult eclosion and greatly affected fecundity in Platynota idaeusalis (Walker, 1859) (Lep.: Tortricidae) (Biddinger et al. 1998).

The tomato leafminer, Tuta absoluta (Meyrick, 1917) (Lep.: Gelechiidae) originates from South America (Giordano et al. 1999) and was recently introduced into Europe and North Africa (Garcia and Vercher 2010). This pest has subsequently spread to the Middle East and is now threatening all of Asia (Desneux et al. 2011). Its larvae mine leaves and bore not only into fruits but also stems (Picanco et al. 1998; Picanco et al. 2007). Up to date chemical control is the main control method towards T. absoluta infestation (Siqueira et al. 2000; Urbaneja et al. 2012; Calvo et al. 2012).

There is little information on the sublethal effects of abamectin on T. absoluta. Given the likely increase in the use of this pesticide in agriculture, it is necessary to examine its effects on the biology of T. absoluta. The purpose of the present study was to evaluate the sublethal effects of abamectin on biological characteristics of T. absoluta, including developmental time, fecundity and mortalities at various life stages and adult emergence. We also compared the pupal weights of individuals treated with sublethal doses of abamectin and the control.

\section{Materials and Methods}

\section{Insect rearing}

The initial T. absoluta populations from different developmental stages were collected in August 2012 from infested greenhouse tomato crops in Karaj, Iran without abamectin exposure. The leaves of non-treated tomato plants (grown in a laboratory greenhouse) were used for egg laying. About 500 adults of T. $a b$ soluta were placed in a plastic cage $(50 \times 30 \times 30 \mathrm{~cm})$ and were transferred onto tomato leaves to continue their growth and development. The insect culture was maintained at $25 \pm 2^{\circ} \mathrm{C}$ and $65 \pm 10 \%$ relative humidity (RH) with a photoperiod of $16: 8 \mathrm{~h}(\mathrm{~L}: \mathrm{D})$ in a growth chamber (Gharekhani and Salek-Ebrahimi 2014).

\section{Bioassay for $\mathrm{LC}_{30}$ and $L C_{50}$ evaluation}

The insecticide solutions were diluted in water containing $0.01 \%$ Triton X-100 and a control treatment (water with $0.01 \%$ Triton) was used to record natural mortality (IRAC 2011). Distilled water without insecticide was used as the control. Leaves were individually dipped in fresh solutions of the insecticide for $10 \mathrm{~s}$ with gentle agitation to ensure equal covering of the entire surface. Then, the treated leaves were left until they dry (Niedmann and Meza-Basso 2006). Insecticide-treated tomato leaves (one leaf) were placed in Petri dishes ( $9 \mathrm{~cm}$ diameter) with ten 4 th instar larvae of the tomato borer that had not been fed for $2 \mathrm{~h}$ and were maintained under controlled environmental conditions [25 $\pm 1^{\circ} \mathrm{C}, 65 \pm 5 \% \mathrm{RH}$ and $12: 12 \mathrm{~h}(\mathrm{~L}: \mathrm{D})$ photoperiod] until the end of the experimental procedure (Lietti et al. 2005). Each treatment was replicated five times with 20 larvae in each replication. Larval mortality was assessed after $48 \mathrm{~h}$ of exposure by prodding the insects with a fine hairbrush. Larvae were considered dead if they were unable to move the length of their body.

\section{Treatment of sublethal doses of abamectin}

Tomato leaf disks treated with $\mathrm{LC}_{10}$ and $\mathrm{LC}_{30}$ of abamectin were used to investigate the sublethal effect of abamectin. After drying, 20 fourth instar larvae that had not eaten for $2 \mathrm{~h}$, were placed on treated leaves in a plastic cup (3 cm deep and $5.5 \mathrm{~cm}$ diameter). Five replicates were used for each treatment. After $48 \mathrm{~h}$, live larvae were transferred onto untreated tomato leaves. The tomato leaves were replaced every $48 \mathrm{~h}$ and the larvae were allowed to grow until they reached the pupal stage. Pupae were placed individually in Petri dishes (8 $\mathrm{cm}$ diameter) until adults emerged. Also, 50 twoday old pupae were randomly selected and weighed individually in each treatment group. After adult emergence, 20 pairs of adults of each sublethal dose and the control were selected and each pair (male and female) was placed in a plastic cage $(14 \times 11 \times 5 \mathrm{~cm})$. A $10 \%$ sugar solution was used as a food source. Adults were allowed to lay eggs on tomato leaves for $72 \mathrm{~h}$. Leaves were replaced and the numbers of eggs laid were recorded daily. This process continued until adult death.

\section{Developmental period}

To estimate the egg developmental period for each treatment, 100 eggs were studied for six days until they hatched. For larval and pupal developmental periods, hatched, live larvae were selected from each concentration and the control. Larvae were placed individually on pieces of tomato leaf in $8 \mathrm{~cm}$ Petri dishes (two leaves/each dish) and the developmental period was recorded daily until adult death. Also survivorship of different stages was recorded, separately. 


\section{Data analysis}

The raw life-history data of all individuals were analyzed according to their age, stage, two-sex life table (Chi and Liu 1985) according to Chi (1988). To facilitate raw data analysis and life-table analysis, the bootstrap method and TWOSEX-MSChart were used to estimate parameters (Chi 2005). The age-stage specific survival rate $\left(S_{x j}\right)$ (where $x$ is the age and $j$ is the stage), age-stage specific fecundity $\left(f_{x j}\right)$, age-specific survival rate $\left(l_{x}\right)$, age-specific fecundity $\left(m_{x}\right)$ and population parameters $(r$ - intrinsic rate of increase; $\lambda$ - finite rate of increase; $R_{0}$ - net reproduction rate; and $T$ - the mean generation time) were calculated accordingly.

The intrinsic rate of increase was estimated using the iterative bisection method from the Euler-Lotka formula (see below), with age indexed from 0 (Goodman 1982). The population parameters of each cohort were estimated as follows:

- intrinsic rate of increase $(r)$ :

$$
\sum_{x=0}^{\infty} e^{-r(x+1)} l_{x} m_{x}=1
$$

- mean generation time $(T)$ :

$$
T=\left(\ln R_{0}\right) / r
$$

- net reproductive rate $\left(R_{0}\right)$ :

$$
e^{r T}=R_{0} \text { or } \lambda^{T}=R_{0},
$$

- gross reproductive rate $(G R R)$ :

$$
G R R=\sum m_{x}
$$

- finite rate of increase

$$
\lambda=e^{r},
$$

where: $l_{x} m_{x}$ - age specific maternity; $m_{x}$ - age specific fecundity.
Bioassay data obtained were subjected to oneway ANOVA ( $\mathrm{p} \leq 0.05)$ after correction for mortality. Means were compared by Tukey's test, admitting significant differences at $\mathrm{p} \leq 0.05$. SPSS 19.0 software was used for mean comparisons. Differences in biological parameters were tested with the bootstrap method (Efron and Tibshirani 1993).

\section{Results}

\section{Susceptibility to abamectin}

The results of leaf-dip bioassay of abamectin on the 4 th instars of the tomato leaf miner moth are shown in Table 1 . The values of $\mathrm{LC}_{10}, \mathrm{LC}_{30}$ and $\mathrm{LC}_{50}$ after $24 \mathrm{~h}$ were $0.12,0.15$ and $0.23 \mathrm{mg}$ a.i. $\cdot \mathrm{l}^{-1}$, respectively.

\section{Pupal weight, fecundity and hatchability}

Pupal weight in $\mathrm{LC}_{10}$ and $\mathrm{LC}_{30}$ concentrations and the untreated group in parent and offspring were significantly different (parent: $\mathrm{F}=28.42, \mathrm{p}=0.0001$, $\mathrm{df}=$ $=2.177$ and offspring: $\mathrm{F}=7.25, \mathrm{p}=0.325, \mathrm{df}=2.247$ ) (Fig. 1). There was no significant difference in adult emergence, between parent and offspring of T. absoluta that were exposed to abamectin (Fig. 2). Table 2 reports the sublethal impacts of abamectin on fecundity and percentage of hatchability of T. absoluta, respectively. The fecundity of tomato leaf miner moth treated with abamectin was significantly lower than the control. In contrast, sublethal concentrations of abamectin did not affect hatchability $(\mathrm{F}=1.16, \mathrm{p}<0.2934, \mathrm{df}=2)$. However, the percentage of pupation was significantly decreased in parents, while no significant difference was observed in offspring (Fig. 3).

Table 1. Toxicity of abamectin on 4th instar larvae of Tuta absoluta

\begin{tabular}{lccccccc}
\hline Pesticide & $\mathrm{N}$ & $\mathrm{LC}_{10}{ }^{*}$ & $\mathrm{LC}_{30}$ & $\mathrm{LC}_{50}$ & $\mathrm{Slope} \pm \mathrm{SE}$ & $\chi^{2}$ & $\mathrm{p}$ \\
\hline Abamectin & 600 & $0.12(0.039-0.13)^{* *}$ & $0.15(0.1-0.19)$ & $0.23(0.16-0.29)$ & 0.63 & 0.96 & 0.85 \\
\hline
\end{tabular}

$\mathrm{N}$ - the number of tested insects

${ }^{*} \mathrm{mg}$ a.i. $\cdot \mathrm{I}^{-1}$

${ }^{* *}$ confidence limit of $95 \%$

Table 2. Comparison of fecundity and hatchability and female/all ratio of Tuta absoluta treated with sublethal doses of abamectin and control

\begin{tabular}{cccc}
\hline Concentrations of pesticide & Fecundity & Hatchability [\%] & Female/all \\
\hline Control & $207.29 \pm 1.85 \mathrm{a}$ & $98.52 \pm 0.79 \mathrm{a}$ & $0.50 \pm 0.02 \mathrm{a}$ \\
$\mathrm{LC}_{10}$ & $196.42 \pm 0.50 \mathrm{~b}$ & $96.37 \pm 1.33 \mathrm{a}$ & $0.50 \pm 0.04 \mathrm{a}$ \\
$\mathrm{LC}_{30}$ & $156.02 \pm 0.63 \mathrm{c}$ & $96.71 \pm 0.52 \mathrm{a}$ & $0.45 \pm 0.03 \mathrm{a}$ \\
$\mathrm{P}$ & $<0.0001$ & 0.2934 & 0.4616 \\
$\mathrm{~F}$ & 416.32 & 1.16 & 0.49 \\
$\mathrm{df}$ & 2,53 & 2,6 & 2,6 \\
\hline
\end{tabular}




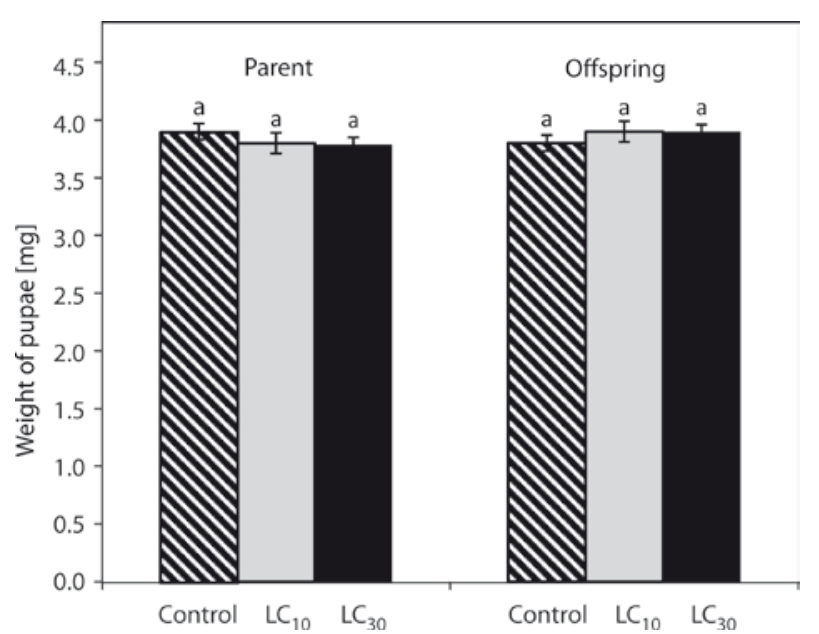

Fig. 1. Pupal weight of Tuta absoluta exposed to abamectin (LC and $\left.\mathrm{LC}_{30}\right)$ and control in parent and offspring. Means marked with same letters are not significantly different ( $p \leq 0.05$; Tukey's test) (parent: $F=28.42, p \leq 0.0001, d f=2.177$; offspring: $F=7.25$, $\mathrm{p} \leq 0.3254, \mathrm{df}=2.247$ )

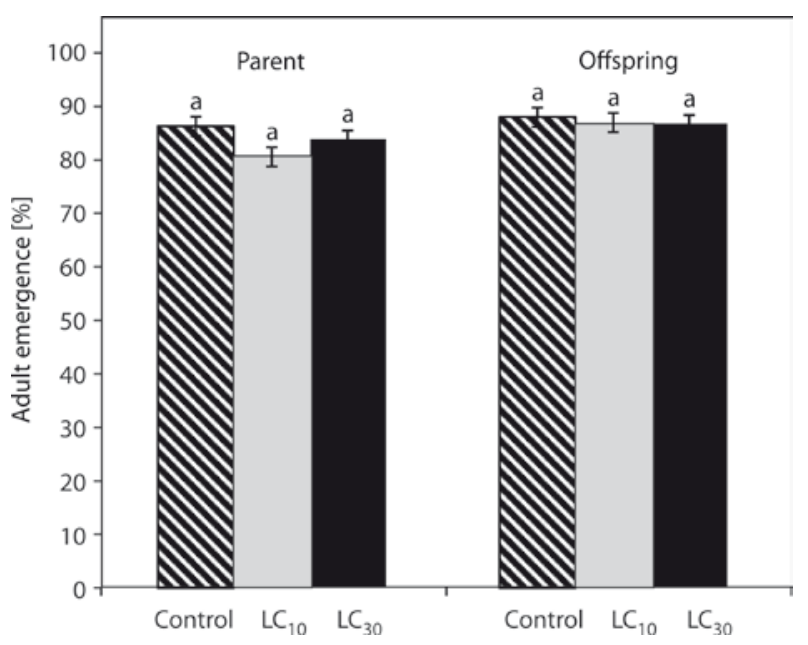

Fig. 2. Adult emergence of Tuta absoluta exposed to abamectin and control in parent and offspring. Means marked with same letters are not significantly different ( $p \leq 0.05$; Tukey's test) (parent: $F=18.42, p \leq 0.238, d f=2.51$; offspring: $F=1.0, p \leq 0.4053$, $\mathrm{df}=2.9$ )

\section{Life history and adult longevity}

The effects of abamectin on eggs, different stages of larva, pre-pupal and pupal developmental time and adult longevity of the T. absoluta are presented in Table 3. The $\mathrm{LC}_{10}$ significantly increased the duration of egg development of T. absoluta. The sublethal doses decreased the L2 and L4 instars' developmental periods. The duration of all larval developmental stages in $\mathrm{LC}_{30}$ concentration was only significantly lower than the control $(\mathrm{F}=3.32, \mathrm{p}=0.038, \mathrm{df}=2)$. Pre-pupa developmental time remained unaffected. The pupa developmental period in the $\mathrm{LC}_{10}$ and $\mathrm{LC}_{30}$ treatment did not cause significant differences compared to the

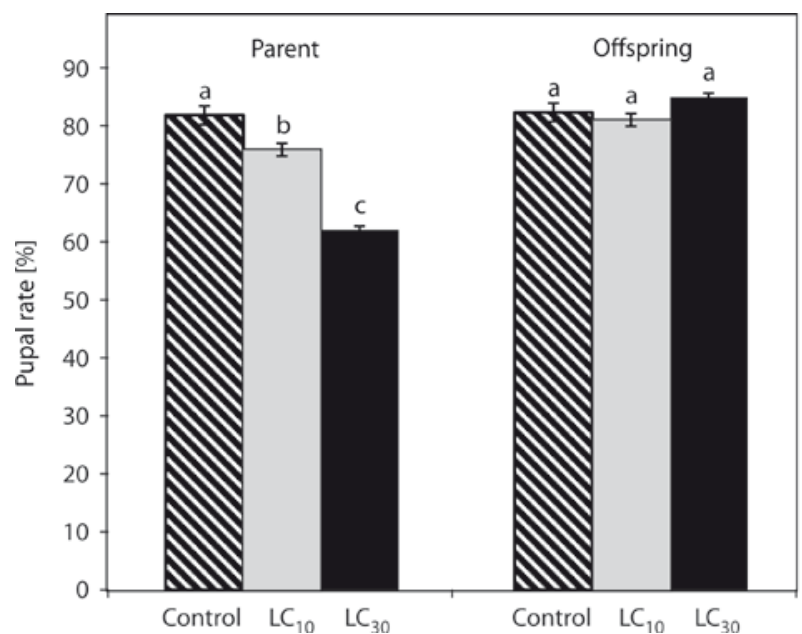

Fig. 3. Percentage of pupation of Tuta absoluta exposed to abamectin and control in parent and offspring. Means marked with different letters are significantly different $(p \leq 0.05$, Tukey's test) (parent: $F=26.32, p \leq 0.0001, d f=2.21$; offspring: $F=0.72$, $\mathrm{p} \leq 0.5116, \mathrm{df}=2.9$ )

control. The mean longevity of males and females in the $\mathrm{LC}_{30}$ treated group was significantly lower than in the control.

\section{Biological parameters}

Survival rates of each life stage of T. absoluta exposed to $\mathrm{LC}_{10}$ and $\mathrm{LC}_{30}$ doses of abamectin and the control are listed in Table 3. In total preposition period in $\mathrm{LC}_{30}$, we observed significant differences. The effect of sublethal doses of abamectin on the survival rate of $T$. absoluta at different stages is shown in Figure 4. The highest rate of mortality was found during the 1 st and 2nd larval instars. The mortality trend of the first larval instar was increased in treatment groups. Also there was a significant difference in the mortality of the second larval instar of T. absoluta. However, mortality in the 3rd and 4th larval instars, pre-pupa and pupa was similar to the controls. Mortality of total larval stages and total pre-adult stages (larva, pre-pupa and pupa) of $T$. absoluta in only $\mathrm{LC}_{30}$ was significantly higher than the controls.

The effects of decreased doses of abamectin on larval instar survival rates are clearly shown in Figure 4. Age-specific survival rate $\left(l_{x}\right)$, female age-stage specific fecundity $\left(F_{x}\right)$, age-specific fecundity $\left(m_{x}\right)$ and age specific maternity $\left(l_{x} m_{x}\right)$ of T. absoluta exposed to sublethal doses of abamectin $\left(\mathrm{LC}_{10}\right.$ and $\left.\mathrm{LC}_{30}\right)$ compared with the control are shown in Figure 5.

The duration of the period during which a female is able to lay eggs decreased with an increased dose of abamectin from $\mathrm{LC}_{10}$ to $\mathrm{LC}_{30}$. Age-stage specific life expectancy $\left(e_{x j}\right)$ of T. absoluta is shown in Figure 6. A decrease in T. absoluta life expectancy was observed 
Table 3. Life-history statistics (mean $\pm \mathrm{SE} ; \mathrm{N}$ ) of Tuta absoluta exposed to sublethal doses $\left(\mathrm{LC}_{10}\right.$ and $\mathrm{LC}_{30}$ ) of abamectin in comparison with control

\begin{tabular}{|c|c|c|c|c|c|c|}
\hline \multirow{2}{*}{$\begin{array}{l}\text { Parameters/ } \\
\text { Developments stages }\end{array}$} & \multicolumn{2}{|c|}{$\mathrm{LC}_{10}$} & \multicolumn{2}{|c|}{$\mathrm{LC}_{30}$} & \multicolumn{2}{|c|}{ Control } \\
\hline & mean $\pm S E$ & $\mathrm{~N}$ & mean $\pm S E$ & $\mathrm{~N}$ & mean $\pm \mathrm{SE}$ & $\mathrm{N}$ \\
\hline Egg & $4.61 \pm 0.068 a^{*}$ & 87 & $4.4 \pm 0.06 \mathrm{~b}$ & 87 & $4.42 \pm 0.05 \mathrm{~b}$ & 88 \\
\hline L1 & $2.37 \pm 0.055 a b$ & 79 & $2.13 \pm 0.039 \mathrm{~b}$ & 77 & $2.46 \pm 0.05 \mathrm{a}$ & 84 \\
\hline L2 & $2.14 \pm 0.041 \mathrm{~b}$ & 73 & $2.06 \pm 0.028 c$ & 69 & $2.4 \pm 0.055 \mathrm{a}$ & 80 \\
\hline L3 & $2.5 \pm 0.062 \mathrm{ab}$ & 66 & $2.22 \pm 0.054 \mathrm{~b}$ & 60 & $2.59 \pm 0.05 \mathrm{a}$ & 73 \\
\hline L4 & $3.32 \pm 0.062 b$ & 66 & $3.02 \pm 0.08 c$ & 55 & $3.71 \pm 0.07 \mathrm{a}$ & 72 \\
\hline Pupa & $8.96 \pm 0.097 \mathrm{a}$ & 53 & $8.52 \pm 0.092 b c$ & 46 & $8.58 \pm 0.088 b$ & 62 \\
\hline Female total pre-adult & $23.89 \pm 0.19 a b$ & 53 & $22.33 \pm 0.162 \mathrm{~b}$ & 46 & $24.19 \pm 0.16 \mathrm{a}$ & 62 \\
\hline Male total pre-adult & $22.93 \pm 0.27 \mathrm{ab}$ & 17 & $21.84 \pm 0.24 b$ & 15 & $23.33 \pm 0.32 \mathrm{a}$ & 22 \\
\hline Female longevity & $37.67 \pm 0.38 \mathrm{~b}$ & 36 & $32.45 \pm 0.42 \mathrm{c}$ & 31 & $39.92 \pm 0.45 \mathrm{a}$ & 40 \\
\hline Male longevity & $36.12 \pm 0.72 \mathrm{ab}$ & 17 & $31.87 \pm 0.4 \mathrm{~b}$ & 15 & $36.68 \pm 0.68 \mathrm{a}$ & 22 \\
\hline $\mathrm{APOP}^{1}$ (days) & 0 & 36 & 0 & 31 & 0 & 40 \\
\hline TPOP $^{2}$ (days) & $23.81 \pm 0.24 \mathrm{ab}$ & 36 & $22.42 \pm 0.195 \mathrm{~b}$ & 31 & $24.2 \pm 0.18 \mathrm{a}$ & 40 \\
\hline Fecundity (eggs/female) & $102.97 \pm 1.6 \mathrm{~b}$ & 36 & $72.32 \pm 1.15 c$ & 31 & $117.6 \pm 1.8 \mathrm{a}$ & 40 \\
\hline
\end{tabular}

$\mathrm{N}$ - the number of tested insects

L1-L4 - larval stages

${ }^{1} \mathrm{APOP}$ - adult pre-oviposition period

${ }^{2}$ TPOP - total pre-oviposition period

${ }^{*}$ means within a row sharing the same letter are not significantly different $(p<0.05$; Tukey's test)

Table 4. Mean $\pm \mathrm{SE}$ of population parameters of Tuta absoluta exposed to $\mathrm{LC}_{10}$ and $\mathrm{LC}_{30}$ of abamectin in comparison with control

\begin{tabular}{cccc}
\hline Population parameters & $\mathrm{LC}_{10}$ & $\mathrm{LC}_{30}$ & Control \\
\hline$r_{\mathrm{m}}$ & $0.1287 \pm 0.010 \mathrm{ab}$ & $0.120654 \pm 0.0041 \mathrm{~b}$ & $0.133799 \pm 0.0036 \mathrm{a}$ \\
$\lambda$ & $1.1373 \pm 0.01 \mathrm{ab}$ & $1.1282 \pm 0.0046 \mathrm{~b}$ & $1.1432 \pm 0.0041 \mathrm{a}$ \\
$G R R$ & $76.42 \pm 2.44 \mathrm{~b}$ & $50.72 \pm 1.83 \mathrm{c}$ & $81.92 \pm 3.28 \mathrm{a}$ \\
$R_{0}$ & $37.07 \pm 5.26 \mathrm{ab}$ & $22.42 \pm 3.72 \mathrm{~b}$ & $47.04 \pm 5.92 \mathrm{a}$ \\
$T$ & $28.07 \pm 0.91 \mathrm{a}$ & $25.78 \pm 1.08 \mathrm{~b}$ & $28.78 \pm 0.87 \mathrm{a}$ \\
$D T$ & $5.39 \pm 0.032 \mathrm{~b}$ & $5.74 \pm 0.046 \mathrm{a}$ & $5.18 \pm 0.071 \mathrm{c}$ \\
\hline
\end{tabular}

$r_{\mathrm{m}}$-intrinsic rate of increase; $\lambda$ - finite rate of increase; $G R R$ - gross reproductive rate; $R_{0}$ - reproductive rate; $T$-generation time; $D T$ - doubling time

due to sublethal doses of abamectin. A reduction in age-stage specific reproductive value $\left(v_{x j}\right)$ of $T$. absoluta exposed to sublethal doses $\left(\mathrm{LC}_{10}\right.$ and $\left.\mathrm{LC}_{30}\right)$ of abamectin showed the retardant potential of this pesticide on the reproduction ability of the tomato leaf miner (Fig. 7). The duration and amount of reproduction in T. absoluta females were reduced.

\section{Population growth parameters}

The effects of sublethal concentrations of abamectin on biological parameters of T. absoluta were compared with the control (Table 4). Gross reproductive rate $(G R R)$ was significantly decreased in the $\mathrm{LC}_{10}$ and $\mathrm{LC}_{30}$ treatments in comparison with the control. $\mathrm{LC}_{30}$ concentrations had significant effects on $R_{0}$ and $r$ in comparison with control. Also, there were significant differences between two sublethal treatments. Doubling time in two sublethal concentrations was significantly increased. Furthermore, doubling time in $\mathrm{LC}_{30}$ concentration was significantly higher than $\mathrm{LC}_{10}$ and the control.

\section{Discussion}

Research on sublethal effects has been to determine the adverse, non-lethal impacts of insecticides on different life history parameters that might affect population dynamics (Stark and Banks 2003). Furthermore, insect pests can develop tolerance toward insecticides in a short time and may even develop resistance after a relatively longer period of exposure by increasing 

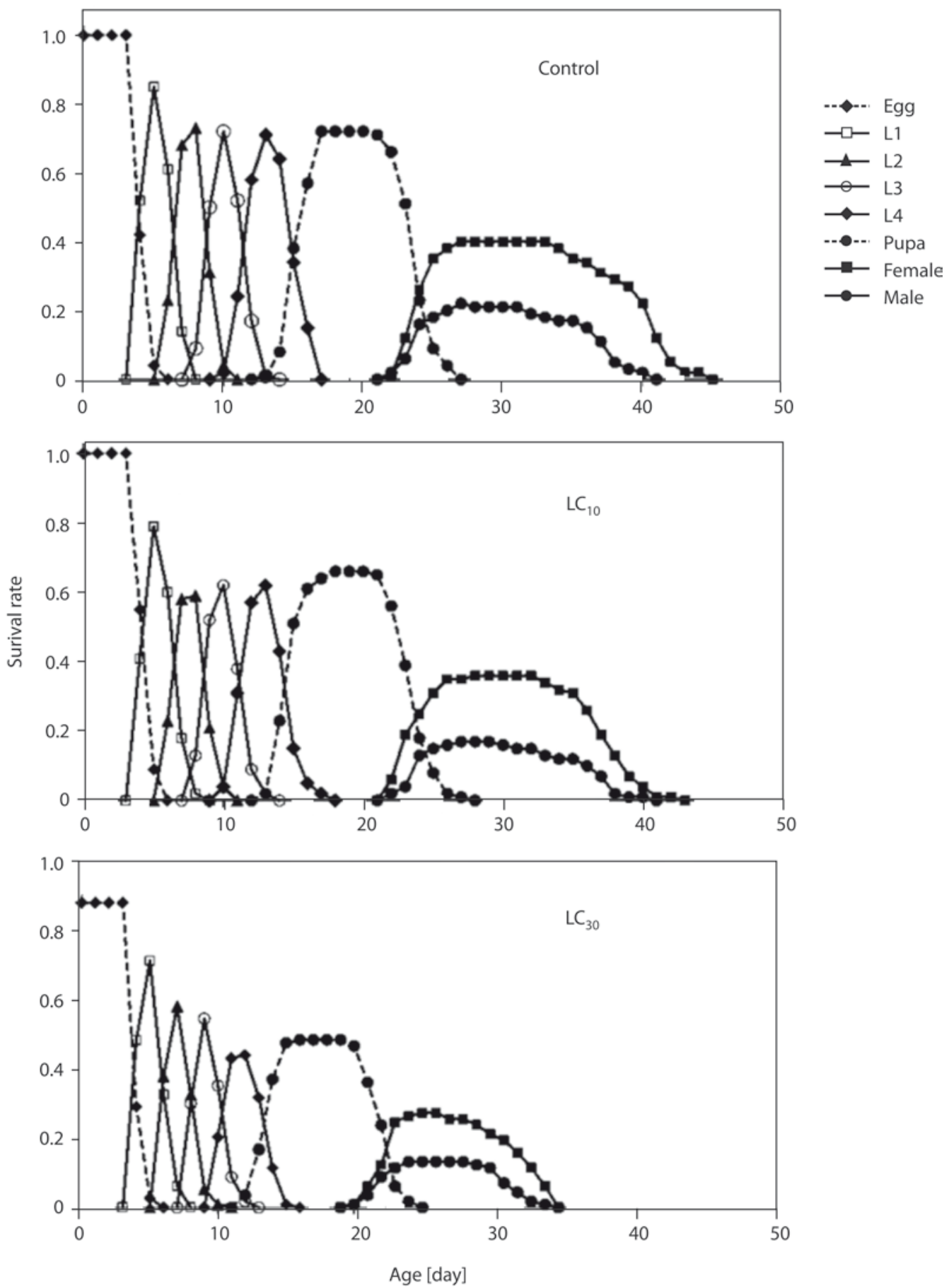

Fig. 4. Age-stage specific survival rate $\left(s_{x}\right)$ of Tuta absoluta exposed to sublethal doses $\left(\mathrm{LC}_{10}\right.$ and $\left.\mathrm{LC} \mathrm{C}_{30}\right)$ of abamectin in comparison with control. L1-L4 - larval stages

the specific activities of metabolic enzymes (Yin et al. 2008). In the present study, it was shown that abamectin is effective against $T$. absoluta through ingestion. Abamectin and pyrethroids were registered against T. absoluta in South America and Europe (Campos et al. 2014). Corbitt et al. (1989) reported that abamectin had the highest toxicity on 1st instar larvae of $\mathrm{He}$ liothis sp. Our results partially support their findings. Also Bueno and Freitas (2004) reported that abamectin had no effect on the eggs of the predator, Chrysoperla externa (Hagen, 1861) (Neuroptera: Chrysopidae). In this study, T. absoluta incubation period was affected by abamectin only in $\mathrm{LC}_{30}$, while life expectancy of eggs was reduced in both $\mathrm{LC}_{10}$ and $\mathrm{LC}_{30}$.

Sublethal doses of abamectin can greatly reduce the feeding and mobility of gypsy moths (Deecher et al. 1990). This effect was allocated to the GABA related mode of action of these compounds that interfere with the motor coordination of muscles involved in feeding and movement. The putative $\mathrm{LC}_{25}$ of abamectin significantly reduced $P$. idaeusalis larval survivorship at 14 days and both rates continued to cause extra 

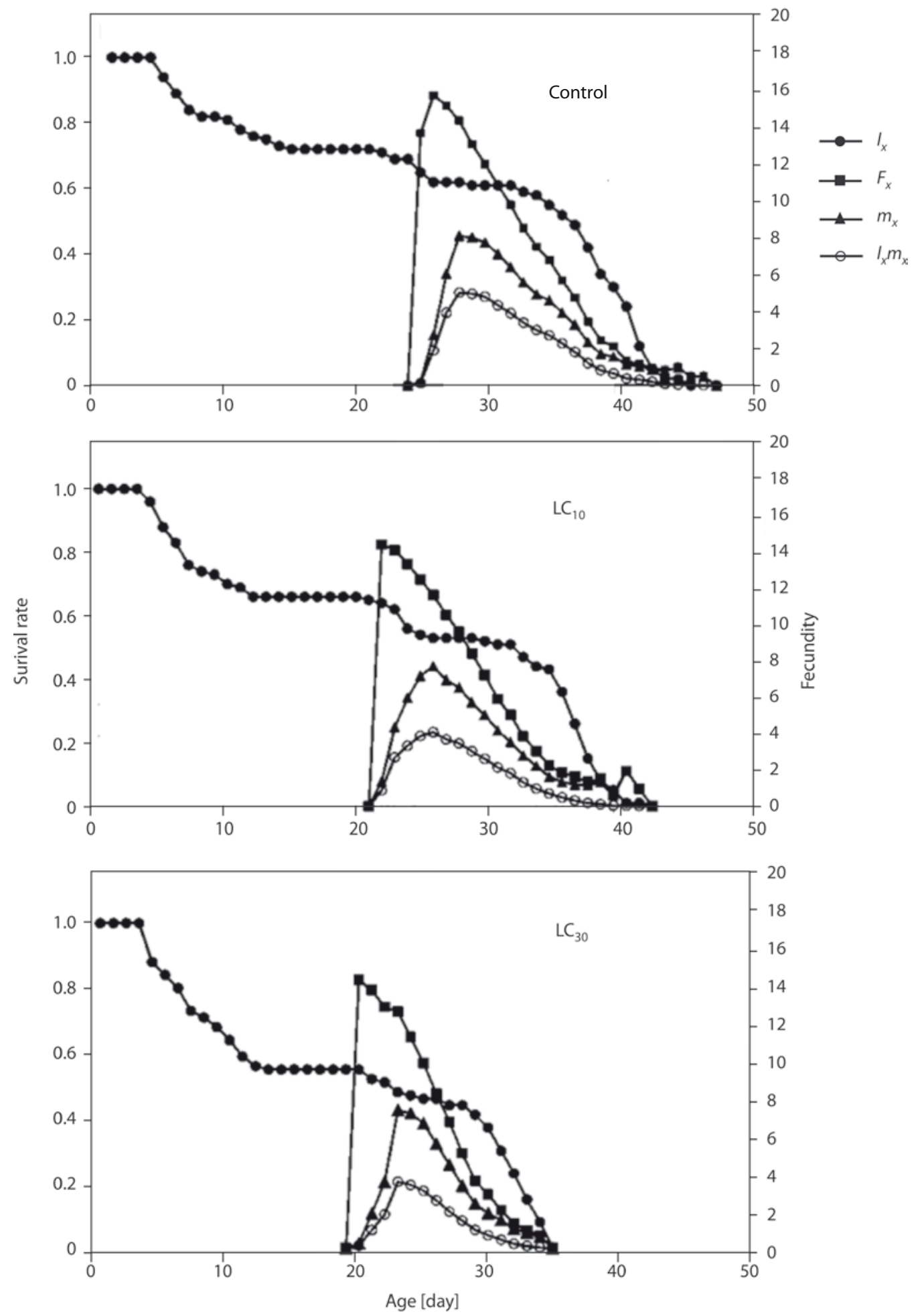

Fig. 5. Age-specific survival rate $\left(I_{x}\right)$, female age-stage specific fecundity $\left(F_{x}\right)$, age-specific fecundity $\left(m_{x}\right)$ and age-specific maternity $\left(I_{x} m_{x}\right)$ of Tuta absoluta exposed to sublethal doses $\left(\mathrm{LC}_{10^{\prime}} \mathrm{LC} \mathrm{C}_{30}\right)$ of abamectin in comparison with control. L1-L4 - larval stages

mortality. Survivorship of pupae of each sex was not affected. These data agreed with dose-mortality regressions (Biddinger et al. 1998) which showed that mortality in P. idaeusalis larvae treated with abamectin increased between 7 and 14 days after first exposure, but did not change after surviving larvae were given an untreated diet. Our results showed a reduction of all larval instars of T. absoluta, while the pupal stage showed enhancement in $\mathrm{LC}_{10}$.

Robertson et al. (1985) showed that additional larval mortality from sublethal doses of abamectin on the Choristoneura occidentalis (Walsingham, 1891) (Lep.: Tortricidae) decreased greatly after 10-15 days. Suckling et al. (1985) found that delayed mortality in 

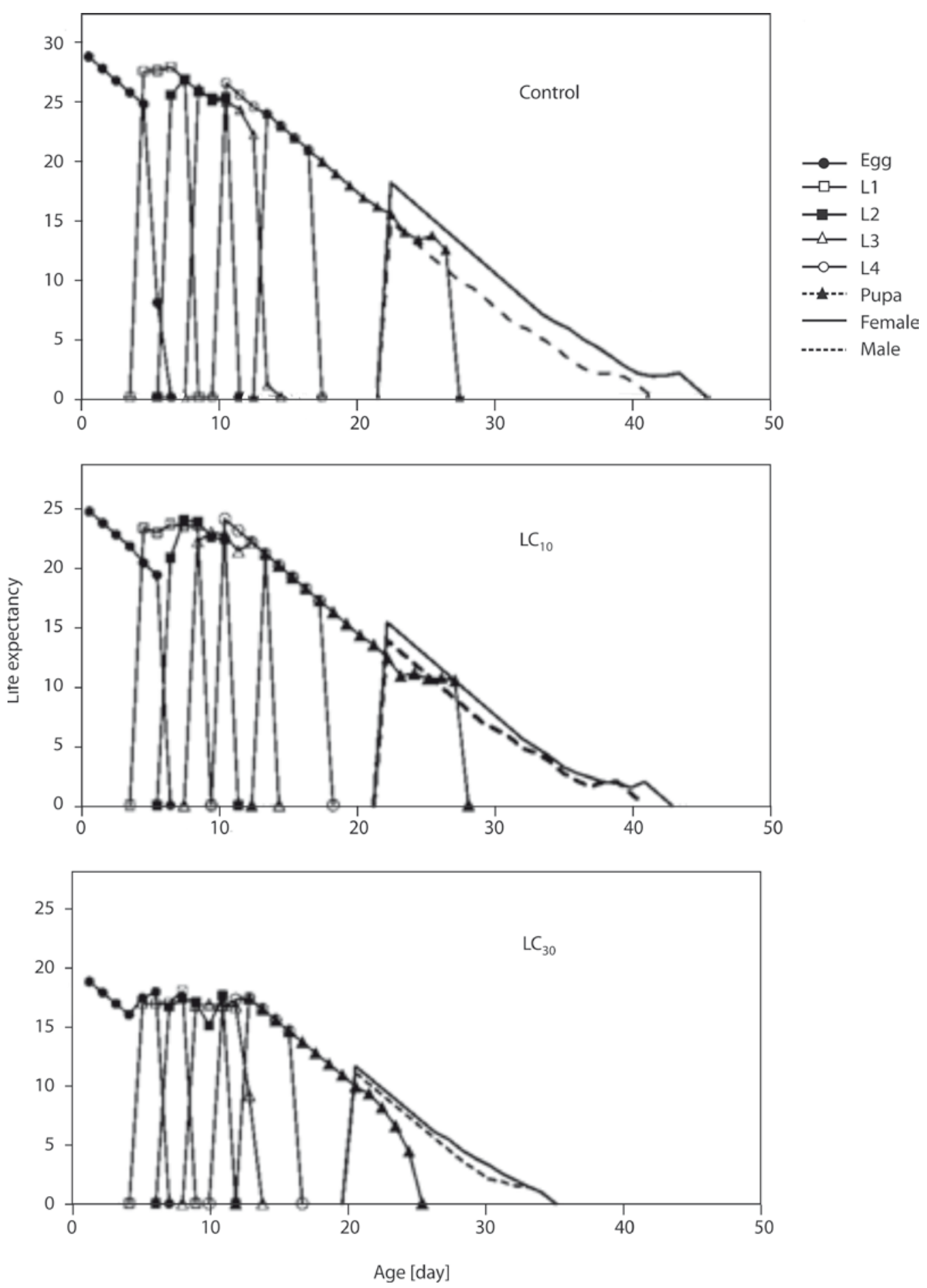

Fig. 6. Age-stage specific life expectancy $\left(e_{x \mathrm{x}}\right)$ of Tuta absoluta exposed to sublethal doses ( $\mathrm{LC}_{10}$ and $\mathrm{LC}_{30}$ ) of abamectin in comparison with control. L1-L4 - larval stages

Epiphyas postvittana (Walker, 1863) (Lep.: Tortricidae) after 21 days of exposure was more than that after 7 days. Most of the previous research has focused on the impact of sublethal doses on beneficial insects but few on the main target pests. The present study revealed that sublethal concentrations of abamectin had important effects on both parent generation and the offspring.

Our results demonstrated that abamectin significantly affected life table parameters of T. absoluta. Hui-
-Dong et al. (2004) reported that emamectin caused a decrease in $r, R_{0}, \lambda$ and $T$ parameters of Plutella $x y$ lostella (Linnaeus, 1758) (Lep.: Plutellidae). Mahdavi et al. (2011) studied sublethal effects of abamectin on the ectoparasitoid Habrobracon hebetor (Say, 1836) (Hym.: Braconidae). Based on their results abamectin is potentially compatible with a chosen Integrated Pest Management (IPM) approach. Hamedi et al. (2011) reported negative effects of abamectin on population growth of predator Phytoseius plumifer (Canestrini and 

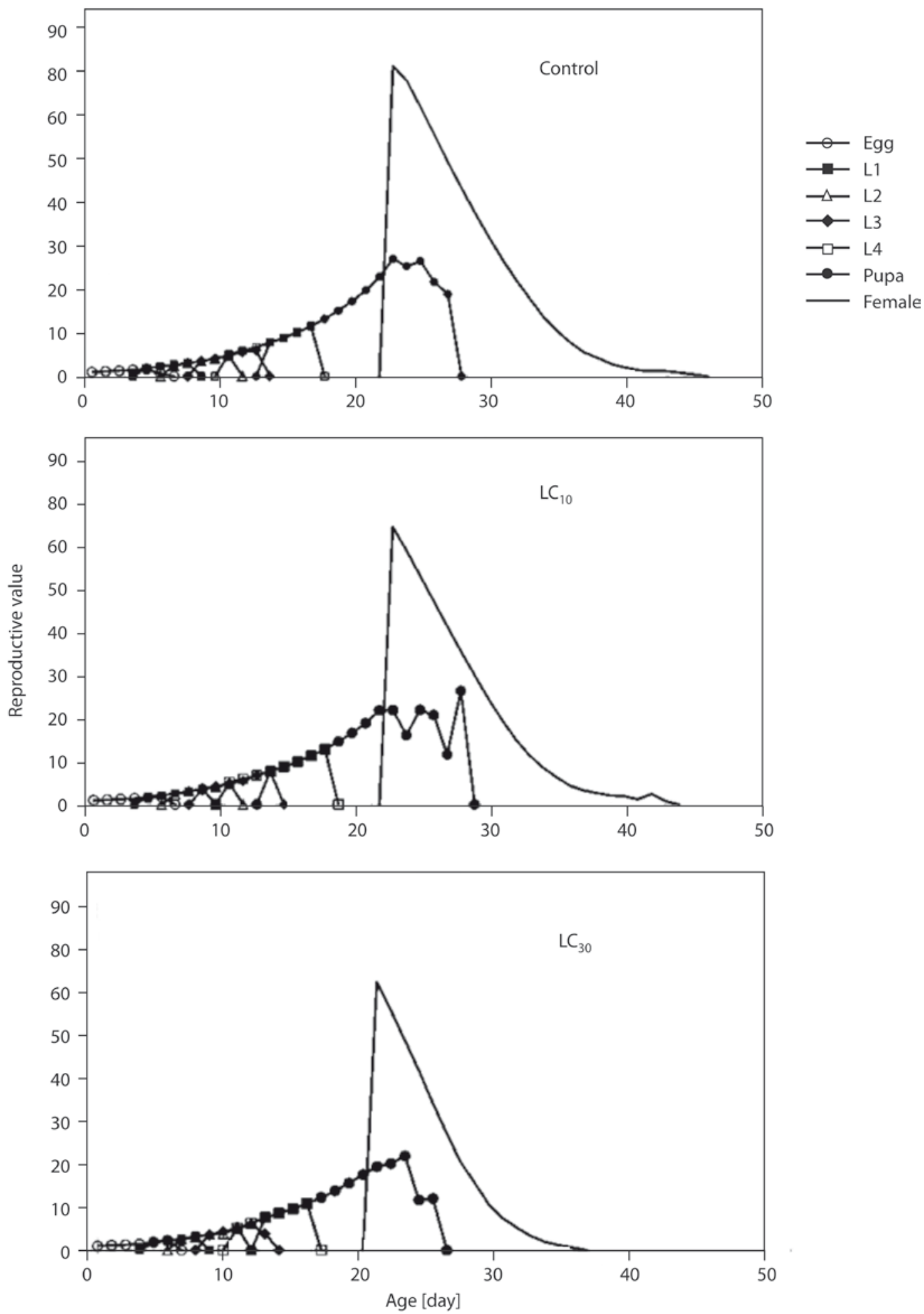

Fig. 7. Age-stage specific reproductive value $\left(v_{x j}\right)$ of Tuta absoluta exposed to sublethal doses $\left(\mathrm{LC}_{10}\right.$ and $\left.\mathrm{LC} \mathrm{C}_{30}\right)$ of abamectin. L1-L4 - larval stages

Fanzago, 1876) (Acari: Phytoseiidae). They showed that their results can be used to develop approximate guidelines for the use of abamectin to decrease their effects on P. plumifer and related natural enemies. Also, our results showed that the survival of the offspring of T. absoluta was significantly reduced when the parent larvae were treated with sublethal concentrations of abamectin. Normally, the effects of abamectin on biological characteristics were greater in the $\mathrm{LC}_{30}$ treatment group and the impacts on the offspring were less than those on the parent generation.

In this study, hormoligosis was not observed in T. absoluta treated with sublethal doses of abamectin. The fecundity of $T$. absoluta females decreased when the larvae were treated with abamectin at $\mathrm{LC}_{10}$ or $\mathrm{LC}_{30}$, but the fecundity of female offspring of treated parents 
was higher than that of untreated females, although the difference was not significant. Other studies have also shown harmful effects on reproduction with sublethal doses of abamectin on lepidopteran and dipteran pests (Strong and Brown 1987). Lepidopteran adults treated as larvae with abamectin have generally been shown to have difficulties in mating (Beach and Todd 1985) or reduced fecundity and fertility (Reed et al. 1985; Robertson et al. 1985; Strong and Brown 1987). Abamectin does not seem to affect reproduction by inducing sterility, but by preventing mating; this, in turn, suppresses oviposition and egg laying (Bariola 1984; Beach and Todd 1985; Strong and Brown 1987). The mechanism of mating prevention has not been determined in Lepidoptera, but appears to be related to changes in behavior.

The degree of the sublethal effects of abamectin that affect the next generation is unclear. Our study showed that an insect pest could be gradually restored to a normal state generation by generation. The endpoint of a sublethal effect depends on the insect species, application dose and the insecticide class. The reduction in fecundity that occurs in an insect has been related to physiological and morphological changes in both males and females of various orders, including insects and Acari (Marco and Sandoval 1999; Saenz-de-Cabezon et al. 2002, 2006). In the current study, we had no significant reduction in pupal weight of T. absoluta in parents and the next generation after the 4th instars were treated with abamectin at the $\mathrm{LC}_{10}$ or $\mathrm{LC}_{30}$. Biddinger et al. (1998) did not observe any increase in pupal duration. Lashkari et al. (2007) showed that intrinsic rates of increase of Brevicoryne brassicae (Linnaeus, 1758) (Hem.: Aphididae) were lower in populations treated with sublethal concentrations of imidacloprid and pymetrozine than in controls. In the present study, the larval developmental time, adult preoviposition period and total preoviposition period tended to be lower in the treatment groups than in the control.

Decreasing fecundity is a major factor to success in pest management. Hatchability of Callosobruchus maculatus (Fabricius, 1775) (Col.: Bruchidae) decreased significantly in treatments of hexaflumuron and pyriproxyfen (Abo-Elghar et al. 2003). In this study, decreased fecundity, adult longevity and developmental time of T. absoluta were similar to the results of Kellouche and Soltani (2006) utilizing a different insect. Also, fecundity was diminished in the treatment group but larval and pupal developmental time did not change. According to these results, abamectin was able to change hatchability of the T. absoluta. As in our research, Wilson and Cryan (1997) revealed that lufenuron, reduced the hatchability of Drosophila melanogaster (Meigen, 1830) (Diptera: Drosophilidae). Consoli et al. (2001) found that the survival rate of Trichogramma galloi (Zucchi, 1988) (Hym.:
Trichogrammatidae) which were treated by lufenuron and triflumuron in the egg-larva and pre-pupal stages was significantly lower than the control. Biddinger et al. (1998) revealed that an insect growth regulator (IGR), diflubenzurun did not affect pupal duration time and pupal survivorship of females of $P$. idaeusalis. In the current study, the survival of larval stages of T. absoluta was reduced in the offspring generation. Physiological effects in the parent generation resulted in diminished survival of offspring. Saenz-de-Cabezon et al. (2006) revealed a decline in the rates of survival, gross reproduction, net reproduction and intrinsic increase $(r)$ of Tetranychus urticae (Koch) (Acari: Tetranychidae) which had been treated with triflumuron, as an IGR. In another study Yin et al. (2008), found that $\mathrm{LC}_{25}$ and $\mathrm{LC}_{50}$ concentrations of spinosad lowered the intrinsic rate of increase, net reproduction rate, gross reproduction rate and increased doubling time in P. xylostella. Lashkari et al. (2007) showed that imidacloprid and pymetrozine reduced $r, R_{0}, \lambda$ (finite rate of increase) and increased $T$ and DT of cabbage aphid, B. brassicae.

Using sublethal doses of abamectin, the mean generation time of T. absoluta was reduced. The values of intrinsic rate of increase $(r)$, finite rate of increase $(\lambda)$, gross reproduction rate $(G R R)$ and net reproductive rate $\left(R_{0}\right)$ tended to be lower in the $\mathrm{LC}_{10}$ or $\mathrm{LC}_{30}$ treatment groups than in the control. Therefore abamectin caused sublethal effects on T. absoluta that may affect population dynamics in the field via reductions in survival and reproduction rates. To identify this, more research in field and laboratory is needed. Hosseini-Tabesh et al. (2015) showed that life table parameters of A. gossypii were significantly different under field and laboratory conditions. In summary, the present results suggest that abamectin has an effective role on larval stages of the T. absoluta. Also sublethal doses of abamectin had effects on T. absoluta, such as reduction in pupal weight, total survival rate, adult longevity, female fecundity and other biological parameters.

Sublethal doses of abamectin had significant effects on the biotic performance of both parent and offspring of T. absoluta. Therefore it may provide more benefits to an integrated pest management program for T. absoluta than conventional pesticides that have high acute toxicity. Our data also highlight the restriction of insecticide studies that are based only on acute toxicity. However research is needed to investigate the sublethal effects of abamectin on the 3rd or later generations and intensive work is required to evaluate the sublethal effects on field populations of insects.

\section{Acknowledgements}

We appreciate the University of Tehran, for the financial support of this study. 


\section{References}

Abo-Elghar G.E., El-Sheikh A.E., El-Sayed F.M., El-Maghraby H.M., El-Zun H.M. 2004. Persistence and residual activity of an organophosphate, pirimiphos-methyl, and three IGRs, hexaflumuron, teflubenzuron and pyriproxyfen, against the cowpea weevil, Callosobruchus maculatus (Coleoptera: Bruchidae). Pest Management Science 60 (1): 95-102. DOI:10.1002/ps.783

Bariola L.A. 1984. Pink bollworms (Lepidoptera: Gelechiidae): effects of low concentrations of selected insecticides on mating and fecundity in the laboratory. Journal of Economic Entomology 77 (5): 1278-1282. DOI: https://doi. org/10.1093/jee/77.5.1278

Beach M.R., Todd J.W. 1985. Toxicity of avermectin to larva and adult soybean looper (Lepidoptera: Noctuidae) and influence on larva feeding and adult fertility and fecundity. Journal of Economic Entomology 78 (5): 1125-1128. DOI: https://doi.org/10.1093/jee/78.5.1125

Biddinger D., Hull L., Rajotte E. 1998. Stage specificity of various insecticides to tufted apple bud moth larvae (Lepidoptera: Tortricidae). Journal of Economic Entomology 91 (1): 200-208. DOI: https://doi.org/10.1093/jee/91.1.200

Bueno A., Freitas S. 2004. Effect of the insecticides abamectin and lufenuron on eggs and larvae of Chrysoperla externa under laboratory conditions. BioControl 49 (3): 277-283. DOI: $10.1023 / \mathrm{B}: \mathrm{BICO} .0000025375 .07428 .0 \mathrm{~b}$

Calvo F.J., Lorente M.J., Stansly P.A., Belda J.E. 2012. Preplant release of Nesidiocoris tenuis and supplementary tactics for control of Tuta absoluta and Bemisia tabaci in greenhouse tomato. Entomologia Experimentalis et Applicata 143 (12): 111-119. DOI: 10.1111/j.1570-7458.2012.01238.x

Campos M.R., Rodrigues A.R.S., Silva W.M., Silva T.B.M., Silva V.R.F. 2014. Spinosad and the Tomato Borer Tuta absoluta: A Bioinsecticide, an Invasive Pest Threat, and High Insecticide Resistance Plos One 9 (8). DOI: 10.1371/journal. pone. 0103235

Chi H., Liu H. 1985. Two new methods for the study of insect population ecology. Bulletin of the Institute of Zoology, Academia Sinica 24 (2): 225-240.

Chi H. 1988. Life-table analysis incorporating both sexes and variable development rates among individuals. Environmental Entomology 17 (1): 26-34. DOI: 10.1093/ee/17.1.26

Chi H. 2005. TWOSEX-MSChart: a computer program for the age-stage, two-sex life table analysis. Taichung, Taiwan: National Chung Hsing University, Taichung, Taiwan. Available on: http://140.120.197.173/Ecology/prod02.htm

Clark J., Scott J., Campos F., Bloomquist J. 1995. Resistance to avermectins: extent, mechanisms, and management implications. Annual Review of Entomology 40 (1): 1-30. DOI: 10.1146/annurev.en.40.010195.000245

Cloyd R. 2012. Indirect effects of pesticides on natural enemies. InTech Open Access Publisher. DOI: 10.5772/48649

Consoli F., Botelho P., Parra J. 2001. Selectivity of insecticides to the egg parasitoid Trichogramma galloi Zucchi (Hym., Trichogrammatidae). Journal of Applied Entomology 125 (1-2): 37-43. DOI: 10.1111/j.1439-0418.2001.00513.x

Corbitt T., StGreen A., Wright D. 1989. Relative potency of abamectin against larval stages of Spodoptera littoralis (Boisd.), Heliothis armigera (Hübn.) and Heliothis virescens (F.) (Lepidoptera: Noctuidae). Crop Protection 8 (2): 127-132. DOI: 10.1016/0261-2194(89)90088-4

Dabrowski Z. 1969. Laboratory studies on the toxicity of pesticides for Typhlodromus finlandicus (Oud.) and Phytoseius macropilis (Banks) (Phytoseiidae, Acarina). Roczniki Nauk Rolniczych 95: 337-369.

Deecher D.C., Brezner J., Tanenbaum S.W. 1990. Sublethal effects of avermectin and milbemycin on the gypsy moth (Lepidoptera: Lymantriidae). Journal of Economic Entomology 83 (3): 710-714. DOI: 10.1093/jee/83.3.710
Desneux N., Decourtye A., Delpuech J.M. 2007. The sublethal effects of pesticides on beneficial arthropods. Annual Review of Entomology 52: 81-106. DOI: 10.1146/annurev. ento.52.110405.091440

Desneux N., Luna M.G., Guillemaud T., Urbaneja A. 2011. The invasive South American tomato pinworm, Tuta absoluta, continues to spread in Afro-Eurasia and beyond: the new threat to tomato world production. Journal of Pest Science 84 (4): 403-408. DOI: 10.1007/s10340-011-0398-6

Efron B., Tibshirani R.J. 1994. An introduction to the bootstrap: CRC press. DOI: 10.1111/1467-9639.00050

El Hassani A.K., Dacher M., Gauthier M., Armengaud C. 2005. Effects of sublethal doses of fipronil on the behavior of the honeybee (Apis mellifera). Pharmacology Biochemistry and Behavior 82 (1): 30-39. DOI: 10.1016/j.pbb.2005.07.008

Fujiwara Y., Takahashi T., Yoshioka T., Nakasuji F. 2002. Changes in egg size of the diamondback moth Plutella $x y$ lostella (Lepidoptera: Yponomeutidae) treated with fenvalerate at sublethal doses and viability of the eggs. Applied Entomology and Zoology 37 (1): 103-109. DOI: 10.1303/ aez.2002.103

García Marí F., Vercher R. 2010. [Description, origin and expansion of Tuta absoluta (Lepidoptera: Gelechiidae)]. Phytoma España 217: 16-20. (in Spanish)

Gharekhani G.H., Salek-Ebrahimi H. 2014. Life table parameters of Tuta absoluta (Lepidoptera: Gelechiidae) on different varieties of tomato. Journal of Economic Entomology 107 (5): 1765-1770. DOI: 10.1603/EC14059

Giordano L.D.B., Silva C., Borém A. 1999. Hibridação em tomate. p. 537-558. In:"Hibridação Artificial De Plantas" (A. Borem, ed.). Universidade Federal de Viçosa (UFV), Portugal, $625 \mathrm{pp}$.

Goodman D. 1982. Optimal life histories, optimal notation, and the value of reproductive value. American Naturalist 119 (6): 803-823. DOI: https://doi.org/10.1086/283956

Hamedi N., Fathipour Y., Saber M. 2011. Sublethal effects of abmectin on the biological performance of the predatory mite, Phytoseius plumifer (Acari: Phytoseiidae). Experimental and Applied Acarology 53 (1): 29-40. DOI: 10.1007/s10493-010 $-9382-8$

Haynes K.F. 1988. Sublethal effects of neurotoxic insecticides on insect behavior. Annual Review of Entomology 33 (1): 149-168. DOI: $10.1007 \% 2$ Fs10493-010-9382-8

Hosseini-Tabesh B., Sahragard A., Karimi-Malati A. 2015. A laboratory and field condition comparison of life table parameters of Aphis gossypii Glover (Hemiptera: Aphididae). Journal of Plant Protection Research 55 (1): 1-7. DOI: https://doi.org/10.1515/jppr-2015-0001

Hui-Dong L., Fang-Qiang Z., Wan-Chun L. 2004. Toxicity of emamectin to the diamondback moth. Plutella xylostella and the effects on survivors of parent generation treated with sublethal dosage. Acta Ecologica Sinica 47 (2): 193-197.

Jones V.P., Parrella M.P. 1984. The sublethal effects of selected insecticides on life table parameters of Panonychus citri (Acari: Tetranychidae). The Canadian Entomologist 116 (7): 1033-1040. DOI: https://doi.org/10.4039/Ent1161033-7

IRAC (Insecticide Resistance Action Committee). 2011. "Tuta absoluta the tomato leafminer or tomato borer". Recommendations for Sustainable and Effective Resistance Management.

Kellouche A., Soltani N. 2006. Impact of hexaflumuron, a chitin synthesis inhibitor, on growth, development and reproductive performance of the progeny in Callosobruchus maculatus after adult treatments. African Journal of Agriculture Research 1 (3): 57-64.

Lashkari M.R., Sahragard A., Ghadamyari M. 2007. Sublethal effects of imidacloprid and pymetrozine on population growth parameters of cabbage aphid, Brevicoryne brassicae on rapeseed, Brassica napus L. Insect Science 14 (3): 207-212. DOI: 10.1111/j.1744-7917.2007.00145.x 
Lietti M.M., Botto E., Alzogaray R.A. 2005. Insecticide resistance in argentine populations of Tuta absoluta (Meyrick) (Lepidoptera: Gelechiidae). Neotropical Entomology 34 (1): 113-119. DOI: http://dx.doi.org/10.1590/S1519-566X 2005000100016

Mahdavi V., Saber M., Rafiee-Dastjerdi H., Mehrvar A. 2011. Comparative study of the population level effects of carbaryl and abamectin on larval ectoparasitoid Habrobracon hebetor Say (Hymenoptera: Braconidae). BioControl 56 (6): 823-830. DOI: $10.1007 / \mathrm{s} 10526-011-9356-8$

Marco V., Sandoval E.V. 1999. Efectos del RCI hexaflumuron sobre larvas de la polilla mediterránea de la harina Ephestia kuehniella Zeller (Lepidoptera: Pyralidae) en aplicación tópica y por ingestión: influencia de la edad de las larvas tratadas [Effects of RCI hexaflumuron on larvae of Mediterranean moth Ephestia kuehniella Zeller (Lepidoptera: Pyralidae) on topical application and on ingestion: influence of age of treated larvae]. Boletin de Sanidad Vegetal-Plagas 25 (1): 59-68. (in Spanish)

Niedmann L.L., Meza-Basso L. 2006. Evaluación de cepas nativas de Bacillus thuringiensis como una alternativa de manejo integrado de la polilla del tomate (Tuta absoluta Meyrick; Lepidoptera: Gelechiidae) en Chile [Evaluation of native strains of Bacillus thuringiensis as an alternative for integrated management of tomato moth (Tuta absoluta Meyrick; Lepidoptera: Gelechiidae) in Chile]. Agricultura Técnica 66 (3): 235-246. DOI: http://dx.doi.org/10.4067/ S0365-28072006000300002 (in Spanish)

Picanço M., Bacci L., Crespo A., Miranda M., Martins J.C. 2007. Effect of integrated pest management practices on tomato production and conservation of natural enemies. Agriculture Forrest Entomology 9: (4): 327-335. DOI: 10.1111/ j.1461-9563.2007.00346.x

Picanço M., Leite G., Guedes R., Silva E. 1998. Yield loss in trellised tomato affected by insecticidal sprays and plant spacing. Crop Protection 17 (5): 447-452. DOI: https://doi. org/10.1016/S0261-2194(98)00040-4

Reed D.K., Tromley N.J., Reed G.L. 1985. Activity of avermectin B1 against codling moth (Lepidoptera: Olethreutidae). Journal of Economic Entomology 78 (5): 1067-1071. DOI: https://doi.org/10.1093/jee/78.5.1067

Ripper W. 1956. Effect of pesticides on balance of arthropod populations. Annual Review of Entomology 1 (1): 403438. DOI: https://doi.org/10.1146/annurev.en.01.010156. 002155

Robertson J.L., Richmond C.E., Preisler H.K. 1985. Lethal and sublethal effects of avermectin B1 on the western spruce budworm (Lepidoptera: Tortricidae). Journal of Economic Entomology 78 (5): 1129-1132. DOI: https://doi. org/10.1093/jee/78.5.1129
Sáenz-de-Cabezón F., Martínez-Villar E., Moreno F., Marco V., Pérez-Moreno I. 2006. Influence of sublethal exposure to triflumuron on the biological performance of Tetranychus urticae Koch (Acari: Tetranychidae). Spanish Journal of Agriculture Research 4 (2): 167-172. DOI: 10.5424/ sjar/2006042-188

Sáenz-de-Cabezón F., Pérez-Moreno I., Marco V. 2002. Effects of triflumuron on the two-spotted spider mite, Tetranychus urticae (Acari: Tetranichydae). Experimental and Applied Acarology 26 (1): 71-78. DOI: https:// doi.org/10.1023/ A: 1020985605115

Sáenz-de-Cabezón F., Pérez-Moreno I., Zalom F.G., Marco V. 2006. Effects of lufenuron on Lobesia botrana (Lepidoptera: Tortricidae) egg, larval, and adult stages. Journal of Economic Entomology 99 (2): 427-431. DOI: https://doi. org/10.1603/0022-0493-99.2.427

Siqueira H., Guedes R., Picanço M. 2000. Cartap resistance and synergism in populations of Tuta absoluta (Lep., Gelechiidae). Journal of Applied Entomology 124 (5-6): 233-238. DOI: $10.1046 /$ j.1439-0418.2000.00470.x

Stapel J., Cortesero A., Lewis W. 2000. Disruptive sublethal effects of insecticides on biological control: altered foraging ability and life span of a parasitoid after feeding on extrafloral nectar of cotton treated with systemic insecticides. Biological Control 17 (3): 243-249. DOI: https://doi. org/10.1006/bcon.1999.0795

Stark J.D., Banks J.E. 2003. Population-level effects of pesticides and other toxicants on arthropods. Annual Review of Entomology 48 (1): 505-519. DOI: 10.1146/annurev. ento.48.091801.112621

Strong L., Brown T. 1987. Avermectins in insect control and biology: a review. Bulletin of Entomological Research 77 (3): 357-389. DOI: https://doi.org/10.1017/S00074853000118467

Suckling D., Kuijpers L., Rogers D. 1984. Bioassay of some novel insecticides against light brown apple moth larvae. p. 45-49. In: Proceedings of the New Zeland Weed and Pest Control Conference 38. Rôtorua, New Zeland, 13-15 August 1985.

Urbaneja A., González-Cabrera J., Arnó, J., Gabarra R. 2012. Prospects for the biological control of Tuta absoluta in tomatoes of the Mediterranean basin. Pest Management Science 68 (9): 1215-1222. DOI: 10.1002/ps.3344

Wilson T.G., Cryan J.R. 1997. Lufenuron, a chitin-synthesis inhibitor, interrupts development of Drosophila melanogaster. Journal of Experimental Zoology 278 (1): 37-44. DOI: 10.1002/(SICI)1097-010X(19970501)278:1<37::AIDJEZ4>3.0.CO;2-7

Yin X.H., Wu Q.J., Li X.F., Zhang Y.J., Xu B.Y. 2008. Sublethal effects of spinosad on Plutella xylostella (Lepidoptera: Yponomeutidae). Crop Protection 27 (10): 1385-1391. DOI: https://doi.org/10.1016/j.cropro.2008.05.008 